\title{
PENGEMBANGAN LEBAH TRIGONA DI DESA SANDA PUPUAN TABANAN
}

\author{
N. N. C. Kusumawati ${ }^{1}$ I. W. Diara ${ }^{2}$, dan N. N. Yastini ${ }^{3}$
}

\begin{abstract}
ABSTRAK
Pengabdian masyarakat bertujuan untuk mengembangkan lebah trigona untuk peningkatan pendapatan masyarakat dan memanfaatkan potensi daerah di Desa Sanda, Kecamatan Pupuan, Kabupaten Tabanan. Metoda yang diterapkan dalam pemberdayaan masyarakat pada kegiatan PKW adalah sebagai berikut : (1) Koordinasi dan komunikasi secara partisipasi dengan masyarakat untuk memutuskan program perencanaan, operasional dan evaluasi. (2) Penyuluhan dan pemahaman kepada masyarakat dan kelompok peternak tentang program yang akan diterapkan. (3) Pelatihan mengenai penerapan iptek yang akan diberikan ke peternak lebah. (4) Pendampingan secara berkala sampai iptek tersebut dapat dilaksanakan secara mandiri. Kegiatan yang dilakukan meliputi : Penyuluhan dan koordinasi pada kelompok peternak lebah madu , penanaman tanaman penghasil bunga (nektar) bagi lebah madu, pelatihan budidaya berternak lebah madu trigona, pelatihan pembuatan stup, pendampingan budidaya yang benar dan pelatihan panen, pengemasan dan pemasaran madu. Hasil dari kegiatan pengabdian di tahun pertama pada kelompok peternak lebah Minteng Sanda adalah Kelompok ini, sudah dapat membudidayakan lebah tigona dengan benar, sudah bisa membuat stup sendiri dan sudah ada 40 buah stup yang berisi bibit lebah trigona untuk dikembangkan.
\end{abstract}

Kata kunci : pengembangan, lebah trigona, madu, desa Sanda, budidaya

\begin{abstract}
Community service aims to develop Apis trigona to increase community income and utilize the potential of the area in Sanda Village, Pupuan District, Tabanan Regency. The methods applied in community empowerment in PKW activities are as follows: (1) Coordination and communication in participation with the community to decide on planning, operational and evaluation programs. (2) Counseling and understanding to the community and farmer groups about the program to be implemented. (3) Training on the application of science and technology to be given to beekeepers. (4) Regular assistance until the science and technology can be carried out independently. Activities included: Counseling and coordination of honey beekeepers, planting of flower-producing plants (nectar) for honey Apis, training on trigona honey Apis farming, training in making Apis, assisting in proper cultivation and training in harvesting, packaging and marketing of honey. The results of the first year of dedication activities for the Minteng Sanda beekeeper group are this group, it has Apisn able to cultivate the Apis trigona correctly, it has Apisn able to make the stup it self and there are already 40 pieces containing the Apis trigona seeds to be developed.
\end{abstract}

Key words : development, Apis trigona, honey, Sanda village, and cultivation 


\section{PENDAHULUAN}

Kelompok tani lebah Minteng Sanda memelihara lebah kele-kele (Apis trigona) di Desa Sanda, Kecamatan Pupuan, Kabupatan Tabanan, Propinsi Bali, berlokasi 25 km dari pusat kota Tabanan. Kelompok Minteng Sanda beranggotakan 8 orang yang dimulai tahun 2017. Kelompok ini sangat antusias mengembangkan lebah kele-kele (Apis trigona) karena daerah sanda merupakan daerah hutan dan terletak pada ketinggian 225 - $975 \mathrm{~m}$ dari permukaan laut. Daerah Sanda disamping memiliki hutan juga memiliki kebun kopi dengan potensi sumber daya alam untuk lebah madu berupa kesediaan bunga kopi yang berlimpah pada musim berbunga. Di Desa Sanda sebelumnya sudah ada kelompok yang memeliara lebah lokal (Apis cerana ) namun belum memberikan hasil yang maksimal. Lebah lokal sering diserang serangga sehingga banyak yang meninggalkan stupnya.

Melihat permasalahan tersebut mereka memilih mengembangkan lebah kele-kele karena harganya sangat tinggi ( Rp. $700.000-900.000$ ), lebah kele-kele tidak menyengat, dalam pemindahan koloni cukup dengan telurnya .

Tim LPPM Unud (2012) mengadakan kajian di lokasi kegiatan mendapatkan hasil bahwa kelompok lebah madu di Desa Sanda mengadapi beberapa masalah seperti: prekuensi panen madu relatif lama ( $2-6$ bulan), kualitas madu belum maksimal seperti rasa, aroma dan warna sehingga harganya masih murah Rp. 100.000 -.200.000 per liter. Pada tahun 2017 Tim KKN PPM Unud sudah melakukan pengadaan stup sebanyak 20 buah namun belum memberikan hasil yang maksimal. Masalah lainnya adalah masih minimnya wawasan kewirausaan masyarakat khususnya kelompok budidaya lebah Trigona. Hal ini memerlukan pelatihan dan pendampingan dalam manajemen dan pemasaran. Kemampuan manajerial dan pemasaran sangat penting dalam pengembangan kelompok pelaku usaha budidaya dalam bidang pertanian/peternakan untuk membangun usaha yang mandiri (Sardiana, dkk., 2015).

Berdasarkan permasalahan yang dihadapi oleh kelompok lebah di Desa Sanda maka Tim PKW Unud bekerjasama dengan UNDWI Denpasar dan PEMDA Tabanan menyelenggarakan kegiatan selama 3 tahun. Pada tahun pertama salah satu kegiatan yang dilaksanakan adalah pengembangan lebah kele-kele ( Apis trigona) pada kelompok Minteng Sanda. Dengan melihat permasalahan diatas maka lebih mudah diatasi jika melibatkan beberapa disiplin ilmu sehingga pengembangan lebah trigona bisa ditingkatkan.

\section{METODE PELAKSANAAN}

Metode yang diterapkan dalam pengembangan lebah kele-kele (Apis trigona) di Desa Sanda adalah pembinaan kepada kelompok Minteng Sanda melalui : penyuluhan , pelatihan, demplot dan pembinaan. Penyuluhan adalah upaya transfer inovasi kepada kelompok lebah Minteng Sanda melalui kegiatan ceramah dan aplikasi iptek. Untuk meningkatkan pemahaman kelompok lebah penyuluhan dilanjutkan dengan demplot yaitu pembuatan aplikasi inovasi secara langsung di lapangan. Pelatihan adalah proses belajar mengajar untuk meningkatkan kemampuan dan keterampilan peserta. Selanjutnya untuk meningkatkan keterampilan SDM (Sumber Daya Manusia) dalam aplikasi teknologi pengelolaan/pengembangan usaha maka dilakukan program pendampingan. Pendampingan dilakukan oleh dosen yang berkopeten di bidangnya.

\section{HASIL DAN PEMBAHASAN}


Hasil dari kegiatan PKW pada tahun pertama di Desa Sanda, Kecamatan Pupuan, Kabupaten Tabanan, salah satunya adalah pengembangan ternak lebah kele- kele ( Apis trigona). Kegiatan yang telah dilaksanakan yaitu :

a. Pengembangan lebah kele-keke (Apis trigona) oleh Tim PKW kepada kelompok Minteng Sanda bertempat di Desa Sanda. Tim PKW, Ketua dan Anggota Kelompok sepakat untuk rencana pengembangan lebah kele-kele dan menerima program ini.

b. Pengadaan stup dan bibit lebah oleh Tim PKW yang dibeli dari peternak Apis trigona bapak Ketut Surata di Lombok sebanyak 40 stup .

c. Pelatihan budidaya lebah kele-kele (Apis trigona) yang disampaikan oleh bapak I Nyoman Yudi dari Desa Dlod Brawah, Negara. Pelatihan yang diberikan antara lain: pembuatan stup bentuk kotak, pemindahan koloni dari bambu ke stup bentuk kotak, pelatihan teknik panen madu dan pengemasan madu.

d. Penanaman bibit duren kunyit sebanyak 300 pohon di lokasi Taman Teknologi Pertanian di Desa Sanda. Penanaman duren kunyit bertujuan untuk menghasilkan buah duren yang memiliki ciri khas untuk Desa Sanda. Ciri khas duren kunyit yaitu warna kuning dan rasanya manis. Disamping untuk produksi buah duren juga dapat sebagai penghasil nectar untuk lebah.

e. Pendampingan pemilihan lokasi yang tepat untuk penempatan stup. Stup ditempatkan pada tempat terlindung agar tidak kena hujan namun masih mendapat sinar matahari. Stup juga ditempatkan dekat dengan pohon berbunga.

Pelatihan pembukuan dan pemasaran juga diberikan kepada kelompok pembudidaya lebah Trigona Miteng Desa Sanda. Beberapa materi yang diberikan adalah mengenai manajemen kelompok, aturan organisasi dan pembagian tugas pengurus dan anggota. Selain itu, dilatihkan juga mengenai teknik pemasaran, mulai dari pengembangan kemasan yang menarik hingga menjalin kemitraan untuk pemasara. Pada pelatihan dan pendampingan ini juga telah dibuat kerjasama pemasaran dengan peternak besar labah trigona yang sekaligus pengepul/pemasok madu untuk supermarket dan apotik dari Desa Delod Berawah Kecamatan Mendoyo Kabupaten Jembrana.

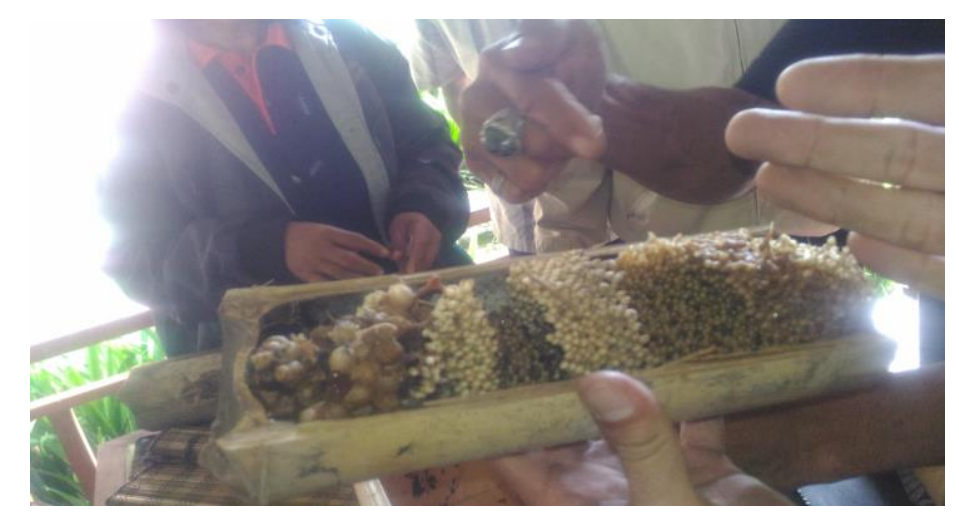

Gambar 3.1. Cara Memisahkan Telur Lebah Trigona 


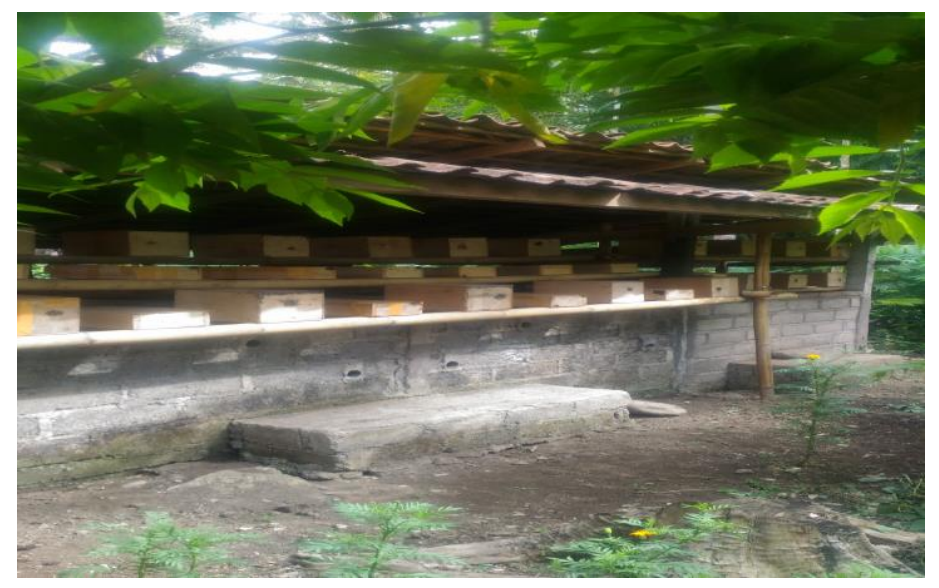

Gambar 3.2. Stup Bentuk Kotak Pada Lebah Trigona

\section{KESIMPULAN}

Kegiatan yang sudah dilaksanakan dapat disimpulkan bahwa Kelompok Lebah Minteng Sanda, di Desa Sanda, Kecamatan Pupuan, Kabupaten Tabanan sudah bisa menerapkan beternak lebah kele-kele ( Apis trigona). Petani lebah sudah bisa memindahkan koloni (bibit lebah), cara panen madu, cara mengemas madu, cara menempatkan stup yang benar dan sudah bisa membuat stup sendiri. Kelompok Minteng Sanda Sudah memiliki 40 stup lebah kele-kele (Apis trigona) yang sudah siap dikembangkan. Kelompok ini juga sudah mengasilkan produk madu yang siap dipasarkan.

Admnistrasi kelompok sudah berjalan baik dicirikan oleh sudah tersedianya pembukuan sederhana, AD/ART, dan papan struktur organisasi.

\section{UCAPAPAN TERIMA KASIH}

Penulis mengucapkan terima kasih kepada KEMENRISTEK DIKTI atas dana yang diberikan lewat program PKW. Pemda Tabanan, UNDWI Denpasar, Rektor Universitas Udayana, Ketua LPPM beserta Staf,. trima kasih atas tenaga yang diberikan dalam pelaksanaan dilapangan, sehingga pengabdian kepada masyarakat terlaksana sesuai rencana.

\section{DAFTAR PUSTAKA}

Badan Statistik Kabupaten Tabanan Propinsi Bali, 2015. Kecamatan Pupuan Dalam Angka. Anon, 2014. Monografi Desa Sanda.

Kuntadi. 2010. Pengembangan Budidaya Lebah Madu dan Permasalahannya. Pusat Penelitian dan Pengembangan Konservasi dan ReabilitasiBadan Penelitian dan Pengembangan Kehutanan.

Sardiana, I.K., B.R.T. Putri, I.G. Suranjaya, N.L.R. Purnawan. 2015. Pengembangan Kewirausahaan Di Universitas Udayana. Majalah Aplikasi Ipteks Ngayah : Vol. 6, No. 1, hal. 91-101

Siti, N.W. , N. W. Suniti dan N.N.Candraasih K. 2017. Perbaikan Produktivitas Madu dari Lebah Madu Lokal (Apis Sp.) Bagi Masyarakat Pinggiran Hutan Kec. Pupuan, Kab. Tabanan. Laporan Hibah KKN PPM Universitas Udayana. 